Int. J. Dev. Biol. 61: 215-224 (2017)

doi: $10.1387 / \mathrm{ijdb} .160285 \mathrm{tb}$

\title{
TAM receptor signaling in development
}

\author{
TAL BURSTYN-COHEN* \\ The Institute for Dental Sciences, Faculty of Dental Medicine, The Hebrew University, Jerusalem, Israel
}

\begin{abstract}
TYRO3, AXL and MERTK comprise the TAM family of receptor protein tyrosine kinases. Activated by their ligands, protein S (PROS1) and growth-arrest-specific 6 (GAS6), they mediate numerous cellular functions throughout development and adulthood. Expressed by a myriad of cell types and tissues, they have been implicated in homeostatic regulation of the immune, nervous, vascular, bone and reproductive systems. The loss-of-function of TAM signaling in adult tissues culminates in the destruction of tissue homeostasis and diseased states, whileTAM gain-of-function in various tumors promotes cancer phenotypes. Combinatorial ligand-receptor interactions may elicit different molecular and cellular responses. Many of the TAM regulatory functions are essentially developmental, taking place both during embryogenesis and postnatally. This review highlights current knowledge on the role of TAM receptors and their ligands during these developmental processes in the immune, nervous, vascular and reproductive systems.
\end{abstract}

KEY WORDS: TAM receptor, TAM signaling, PROS1, Protein S, GAS6

\section{Introduction to TAM functions}

The impact of the TAM family of receptor protein tyrosine kinases (RTKs) on physiology recently gained momentum, as they play pivotal roles in several physiological systems. TYRO3, AXL and MERTK comprise the TAM family of RTKs, and together with their cognate ligands Growth Arrest-Specific 6 (GAS6) and Protein $S$ (PROS1) mediate various molecular signaling pathways and cellular functions, mostly impacting adult tissues. The two chief functions mediated by TAM receptors in adult tissues are the phagocytic uptake of membranes and apoptotic cells, and negative regulation of the immune response (Lemke, 2013). Indeed, TAMs are expressed by professional and non-professional phagocytes in several tissues where they mediate efferocytosis - the process of phagocytic uptake and clearance of apoptotic cells. Removal of apoptotic germ cells and extruded cytoplasm by Sertoli cells in the testis (Lu et al., 1999), efferocytosis by macrophages of the immune system (Anderson et al., 2003) and by brain microglia during adult neurogenesis (Fourgeaud et al., 2016), as well as bone resorption by osteoclasts (Nakamura et al., 1998) are all mediated by TAM signaling (Lemke et al., 2010; Lu et al., 2010). An exception to efferocytic phagocytosis is seen in the retina, where MER is necessary for uptake of viable photoreceptor outer segments by retinal pigment epithelium (RPE) (Burstyn-Cohen et al., 2012; D'Cruz et al., 2000; Duncan et al., 2003; Lu et al., 2010; Prasad et al., 2006). Thus, as part of the "sanitary department", TAMs are pivotal in the rapid clearance of cellular debris, preventing the cells' secondary necrosis and release of intracellular antigens and DNA which provoke inflammation and autoimmunity (Elliott et al., 2010), ultimately leading to failed tissue homeostasis and pathological conditions such as local or systemic inflammation, autoimmunity and cancer (Poon et al., 2014). In keeping with a role in maintaining tissue homeostasis through phagocytosis, mice lacking TAM receptor function develop autoimmune disease (Lu et al., 2001), male infertility (Lu et al., 1999) and blindness (Duncan et al., 2003; Lu et al., 1999). Another central function fulfilled by TAM receptor signaling is their regulatory role in attenuating inflammatory reactions and immune responses. As negative regulators of immunity, TAMs are expressed by a myriad of immune cell populations, where they specifically restrain innate immunity and the secretion of pro-inflammatory cytokines (Carrera Silva et al., 2013; Rothlin et al., 2015; Rothlin et al., 2007). Thus, TAM-mediated homeostatic regulation and diminution of inflammation is brought about by both the active removal of potential stimulators of auto-immune response, as well as by molecular inhibition of inflammation and immune cell activation (Lemke et al., 2008; Rothlin et al., 2015).

While TAM loss-of-function underlies dysregulated tissue homeostasis as mentioned above, it should be mentioned that the overexpression and upregulation of TAMs is recognized in vari-

Abbreviations used in this paper: DKO, double knockout; GAS6, growth-arrest-specific 6; GnRH, gonadotrophin releasing hormone; NSC/NPG, neural stem cell/neural progenitor cell; PROS 1, Protein S; RPE, retinal pigment epithelium; RTK, receptor tyrosine kinase; TAM, Tyro3, Axl, Mertk.

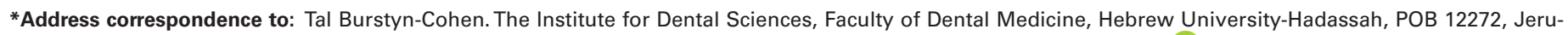

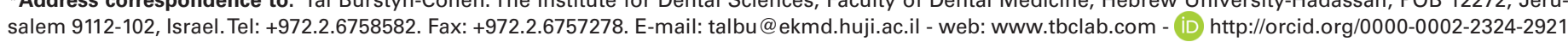

Accepted: 5 October, 2016.

ISSN: Online 1696-3547, Print 0214-6282 
ous human cancers, where activated TAM signaling functionally supports increased proliferation, migration, invasion, enhanced tumor cell survival, angiogenesis and promotes resistance to chemotherapeutic drugs (Axelrod et al., 2014; Cummings et al., 2013; Graham et al., 2014). To date, among TAMs, AXL overexpression was shown to drive chemoresistance in several cancer models (Brand et al., 2014; Elkabets et al., 2015). Thus, taming TAM signaling is critically important for maintaining healthy tissue homeostasis and TAM activation by their ligands PROS1 and GAS6 must also be kept in check.

For many years, the lack of tools to study the roles of the individual TAM receptors and ligands in a cell-specific manner has hampered the understanding of TAM-mediated signaling, especially as different TAM receptor-ligand interactions mediate diverse signaling pathways and altered cellular functions (Graham et al., 2014; Lemke, 2013; Zagorska et al., 2014). The role of GAS6 and PROS1 as TAM agonists was studied in vitro for many years, where the role of PROS1 as a functional TAM ligand was debatable at times. It was only following the development of an organotypic in vitro system (Prasad et al., 2006) and the generation of a conditional knockout mouse model for Pros1 (Burstyn-Cohen et al., 2009) that enabled the uncovering of PROS1 functions as a TAM ligand in may tissues in vivo (Burstyn-Cohen etal., 2009; Burstyn-Cohen etal., 2012; Carrera Silva et al., 2013).

This review highlights previously identified and newly emerging roles of the TAM receptors and their ligands (Fig. 1) during embryonic and postnatal development. The relevance of TAM signaling components to developmental processes and its relation to disease is discussed.

\section{A brief history of the cloning and identifi- cation of TAM receptors and their ligands}

The receptors TYRO3, AXL and MERTK were independently cloned by several labs in the early 1990's (Graham et al., 1994; Lai et al., 1994; Lai et al., 1991; O'Bryan et al., 1991), and their ligands identified as PROS1 and GAS6 several years later (Mark et al., 1996; Nagata et al., 1996; Ohashi et al., 1995; Stitt et al., 1995). However, several laboratories reported the in vitro stimulation of TAM receptors only by GAS6 and not by PROS1 in various experimental systems (Chen et al., 1997; Godowski et al., 1995; Hall et al., 2001; Mark et al., 1996; Nagata etal., 1996; Ohashi etal., 1995), thus questioning the biological role of PROS1 as a functional TAM ligand. It was not until 2003 when Anderson et. al. reported that serum-derived PROS1 stimulated phagocytosis of apoptotic cells by macrophages (Anderson et al., 2003), which was already known to be mediated by MERTK (Scott et al., 2001). A couple of years later PROS1 was reported to stimulate the phagocytic uptake of photoreceptor outer segments by cells of the retinal pigment epithelium (RPE) (Hall et al., 2005;
Prasad et al., 2006). Another line of evidence implying PROS1 as an in vivo TAM ligand stemmed from analysis of two independently generated GAS6 null mouse models (Angelillo-Scherrer et al., 2005; Yanagita et al., 2002). Both GAS6 null strains appeared healthy and were not blind due to photoreceptor degeneration as

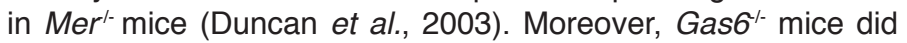
not present with autoimmune disease or male sterility, as do mice lacking all three TAM receptors (Lu et al., 1999; Lu, Lemke, 2001). The generation and analysis of conditional knockout mice for Pros 1 (Burstyn-Cohen et al., 2009) and ablation of Pros1 expression in the retina demonstrated the role of PROS1 as an in vivo ligand for MERTK in mediating the phagocytosis of photoreceptor outer segments by RPE cells (Burstyn-Cohen et al., 2012). The role

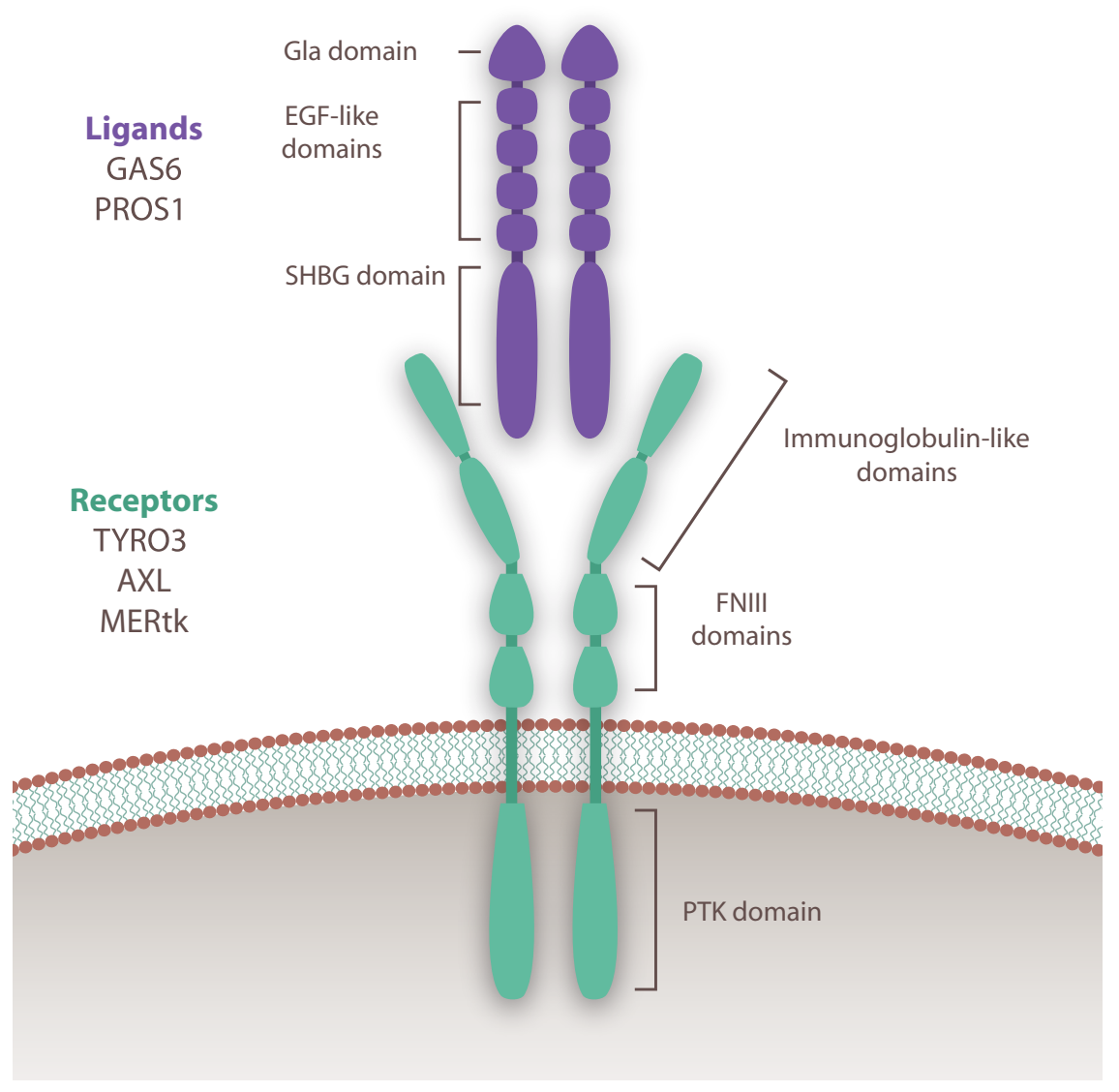

Fig. 1. Structure of the TAM receptor signaling components. The TAM family of receptor tyrosine kinases is comprised of TYRO3, AXL and MERTK. All receptors (shown in green) share a similar domain structure. The extracellular domain is comprised of two immunoglobulin (lg) type domains at the amino-most terminus. Two fibronectin type III domains are located adjacent to the transmembrane domain. Their kinase domain resides intracellularly, mediating various intracellular pathways, including PI3K/AKT, ERK/MAPK and JAK/STAT. The ligands GAS6 and PROS1 (shown in purple) are highly homologous, with similar domain structure and $44 \%$ amino acid identity (MANFIOLETTI et al., 1993). A gamma-carboxy glutamic acid (Gla) domain is located at the amino-terminus, followed by four EGF-like domains. The carboxy-terminal end of the ligands contains two laminin $G$ type domains, which together comprise the sex hormone binding globulin (SHBG) domain. Gamma carboxylation of the Gla domains is vital for ligand bioactivity, and is a vitamin K-dependent reaction. Thus, ligand activity is sensitive to vitamin K levels and inhibitors. The Gla domain may also bind phosphatidylserine moieties exposed on the surface of apoptotic cells and membrane discs of photoreceptors. Receptor dimerization and activation of the tyrosine kinase domain are induced following ligand binding via SHBG domain - Ig domains interaction. 
of PROS1 as a TAM ligand in vivo has since been shown in the adult mouse testis (Lew et al., 2014), and in the immune system (Carrera Silva et al., 2013).

\section{TAM signaling in development}

Overlapping expression and functional redundancies between the TAM receptors prompted the generation of mice in which all three TAM receptors were inactivated (Lu et al., 1999). Simultaneous inactivation of all TAM receptors does not result in embryonic lethality, indicating their regulatory roles are dispensable for development (Lemke, 2013; Lu et al., 1999). However, expanding data suggest the TAMs do regulate developmental processes, as TAM receptors and their ligands are expressed by embryonic stem cells and during development in multiple cell types, and inactivation of TAM receptors or their ligands affects normal embryonic and postnatal developmental processes. The biologic functions of TAM receptors and their ligands in maintaining a healthy homeostasis in adult tissues has been briefly mentioned above, and was recently extensively reviewed (Graham et al., 2014; Lemke, 2013; Lemke, Burstyn-Cohen, 2010; Rothlin et al., 2015; Rothlin et al., 2010). Here, I will focus on the newly emerging roles of TAM signaling in developmental processes.

Notably, the expression of TYRO3 was first reported to be enriched in embryonic developing mouse tissue, and was therefore initially named Developmental Tyrosine Kinase - DTK (Crosier et al., 1994). The expression pattern of DTK -now formally renamed TYRO3 - was highly enriched in embryonic tissues, including undifferentiated mouse embryonic stem (ES) cells and in various embryonic tissues. In contrast to embryonic tissue, TYRO3 expression in adult tissues was restricted to portions of the gastrointestinal, nervous and reproductive systems (Crosier et al., 1994). The embryonic expression of TYRO3 notwithstanding, to date no gross developmental defects have been attributed to the loss of TYRO3 expression. This may be explained by the overlapping and compensatory roles of TAM receptors demonstrated in various cell types, often with an increase in phenotype severity caused by loss of each additional TAM allele (Lemke, 2013; Lu, Lemke, 2001).

\section{TAM receptor function in the developing reproductive system}

Gonadotropin-releasing hormone $(\mathrm{GnRH})$ neurons participate in the hypothaloamic-pituitary-gonadal axis which regulates many aspects of sexual development and maturation in both males and females. In adult rodents and higher mammals, GnRH neurons reside in the hypothalamus, where they secrete $\mathrm{GnRH}$ in a pulsatile manner into the pituitary portal system (Fig. 2). In turn, uptake of $\mathrm{GnRH}$ by the pituitary initiates secretion of the pituitary gonadotropins luteinizing hormone (LH) and follicle-stimulating hormone (FSH) into the circulation. $\mathrm{LH}$ and $\mathrm{FSH}$ stimulate the gonads to promote gametogenesis and steroidgenesis. In males, LH stimulates the production and secretion of testosterone and android-binding protein by Leydig and Sertoli cells of the testis. In females, LH stimulates the ovarian secretion of androgens, as well as secretion of progesterone at later stages. FSH stimulates Sertoli cells to promote the proliferation and post-mitotic maturation of male germ cells, and the production of estradiol by ovarian granulosa cells in females. Deficiencies in $\mathrm{GnRH}$ culminate in the failure to undergo normal pubertal development (Herbison, 2016; Wierman et al., 2011).

During embryogenesis, GnRH neurons undergo extensive migration from their birth location in the olfactory placode/vomeronasal organ to the hypothalamus (Fig. 2). In mice GnRH neurons engage in migration at embryonic day 10.5 (E10.5), when they leave the olfactory placode, migrate along the vomeronasal nerve and traverse into the developing forebrain through perforations at the cribriform plate between E12-E17. Once in the forebrain, $\mathrm{GnRH}$ neurons change their migratory trajectory and turn caudally, until they arrive at their final destination - the hypothalamus. $\mathrm{GnRH}$ neurons further disperse within this region, and finally send projections to the median eminence, activating pituitary gonadotropes. The defective production or incorrect migration of $\mathrm{GnRH}$ neurons underlies reproductive disorders, such as hypogonadotropic hypogonadism as in Kallmann's syndrome (Herbison, 2016; Wierman et al., 2011).

Studying the molecular mechanisms underlying the complex migratory pathway of $\mathrm{GnRH}$ neurons has revealed a role for GAS6/AXL signaling in their guidance, proliferation and survival. The elevated expression of AXL by migratory $\mathrm{GnRH}$ neuron cell lines compared to post-migratory $\mathrm{GnRH}$ neurons suggested its involvement in GnRH migration (Fang et al., 1998). AXL stimulation by GAS 6 in the Gn10 migratory cell line induced activation of extracellular signal-regulated kinase (ERK) and Akt in a GAS6dependent fashion, resulting in increased cell survival and protection from apoptotic cell death (Allen et al., 1999). The expression of all TAM receptor signaling components was later identified to be differentially expressed, with $\mathrm{Axl}$ and Tyro3 predominantly expressed among low $\mathrm{GnRH}$ expressing migratory $\mathrm{GnRH}$ neurons. By contrast, Mer was upregulated in high $\mathrm{GnRH}$ expressing postmigratory neurons, further suggesting their dynamic role in $\mathrm{GnRH}$ development (Pierce et al., 2008).

In vitro silencing of $A x /$ and Tyro3 identified their role in protection of migratory $\mathrm{GnRH}$ neuronal cells from apoptosis induced by growth-factor withdrawal (Pierce et al., 2008). Studying migratory GnRH neurons during embryogenesis in mice deleted for $A x I\left(A x H^{H^{-}}\right)$, Tyro3 ( Tyro3 $^{--}$) or both $\mathrm{Axl}$ and Tyro3 $\left(\mathrm{Ax}^{H^{--}}\right.$, Tyro3 $\left.{ }^{--}\right)$corroborated their roles in vivo. $A x I$ and Tyro3 deficiencies manifested later in adulthood in delayed sexual maturation and irregular estrus cycles with a significantly prolonged proestrus phase - all known to be dependent on GnRH neuronal function (Pierce et al., 2008). The simultaneous deletion of Tyro3 and $A x /$ resulted in increased apoptosis of E15 migratory $\mathrm{GnRH}$ neurons, which led to a diminution of $\mathrm{GnRH}$ neurons reaching the forebrain at E15 as well as reduced $\mathrm{GnRH}$ neuronal populations in adult females (Pierce et al., 2008). These findings indicate a role for TAM receptors in embryonic $\mathrm{GnRH}$ neuronal migration and survival.

To understand whether the TAM cognate ligands GAS6 and/ or PROS1 play a role in GnRH neuronal migration in vivo, a first inspection was attempted in Gas6 $^{--}$mice. Salian-Mehta and colleagues report that Gas6 null females show a delayed vaginal opening and delayed first estrus, although normal estrus cycles were finally obtained later in adulthood (Salian-Mehta et al., 2014). Gas6 KO females had reduced numbers of GnRH neurons and their accumulation in early migratory locations at E15 suggests failed continued migration in the absence of Gas6. It is worthy to note that Gas6 KO mice showed an overall improved phenotype compared to Tyro3; Ax/double knockout (DKO) mice. The normal estrus cyclicity and the modest, yet significant phenotypes described 
in $\mathrm{Gas6}^{- \text {- }}$ females may suggest an in vivo role for PROS1 in $\mathrm{GnRH}$ development, as both GAS6 and PROS1 are expressed during GnRH neuronal development. While GAS6 expression did not differ between migratory and post-migratory $\mathrm{GnRH}$ neurons, that of PROS1 was found to be dynamically upregulated in post-migratory GnRH neurons (Pierce et al., 2008). Whether PROS1 plays a role in $\mathrm{GnRH}$ neuronal development in vivo remains to be investigated.

Less is known about the role of TAMs in development of the male reproductive system. The first indication of TAM function in male (and female) fertility was reported in 1999 by Lu and colleagues (Lu et al., 1999), who revealed that both female ovaries and male testis were histologically abnormal. The triple TAM knockout males never sired offspring, indicating their sterility. This report also identified cell death in the granulosa cells associated with growing ovarian follicles.

The few reports on the role of TAM signaling in the male reproductive system are chiefly based on studies in TAM triple KO mice, and focused at the postnatal perturbed clearance of immature and defective spermatids by Sertoli cells, eventually leading to failed testicular homeostasis and male sterility (Lu et al., 1999). The expression of all TAM receptors was found to be confined to Sertoli cells, while expression of both GAS6 and PROS1 ligands was first detected in Leydig cells, and later upregulated in Sertoli cells coinciding sexual maturation (Lu et al., 1999). Postnatal spermatogenesis is deffective in TAM triple KO mice, with delayed production of mature sperm and increasingly elevated sperm deficiency as these mice mature. Sertoli cell death was observed in these mice, which led to germ cell death during their maturation phase, specifically in spermatids and spermatocytes (Lu et al.,
1999). Interestingly, these mice had normal blood testosterone levels and exhibited normal sexual behavior. Thus, it was hypothesized that TAMs are necessary for Sertoli cells to provide trophic support for the developing spermatogonia. Additionally, the life-long continuous generation of sperm also requires the nonstop phagocytic clearance of apoptotic germ cells and cytoplasm extruded during sperm maturation. This rapid clearance of cell debris is performed by Sertoli cells, (Lu et al., 2010), and is mediated by TAM receptors (Chen et al., 2009; Lemke, Burstyn-Cohen, 2010; Lu et al., 2010; Xiong et al., 2008). GAS6 was shown to mediate Sertoli cell phagocytosis of apoptotic cells in vitro (Xiong et al., 2008), however the viability of Sertoli cells in Gas6 $6^{--}$mice and their fertility suggests that PROS1, also expressed by Leydig cells may function redundantly in vivo. Indeed, MERTK stimulation by PROS1 is sufficient for normal apoptotic cell clearance in the testis, as revealed by a systematic genetic analysis in various TAM single and double mutant mice (Lew et al., 2014).

Sertoli cell progenitors are already present within the developing gonad at E11.5, and were shown to play key roles in further testicular development, including testis cord formation, testicular vasculogenesis, Leydig cell differentiation and function, and the maintenance of undifferentiated spermatogonia (reviewed in Cool et al., 2012). Sertoli cells also play a central role in the continuing prepubertal postnatal development of the testis, including in the postnatal development of Leydig cells, as was recently shown by the postnatal ablation of Sertoli cells (Rebourcet et al., 2014). Whether TAM receptors are expressed by early Sertoli cells or whether they play a role in these embryonic or postnatal stages of testis development has not yet been studied.

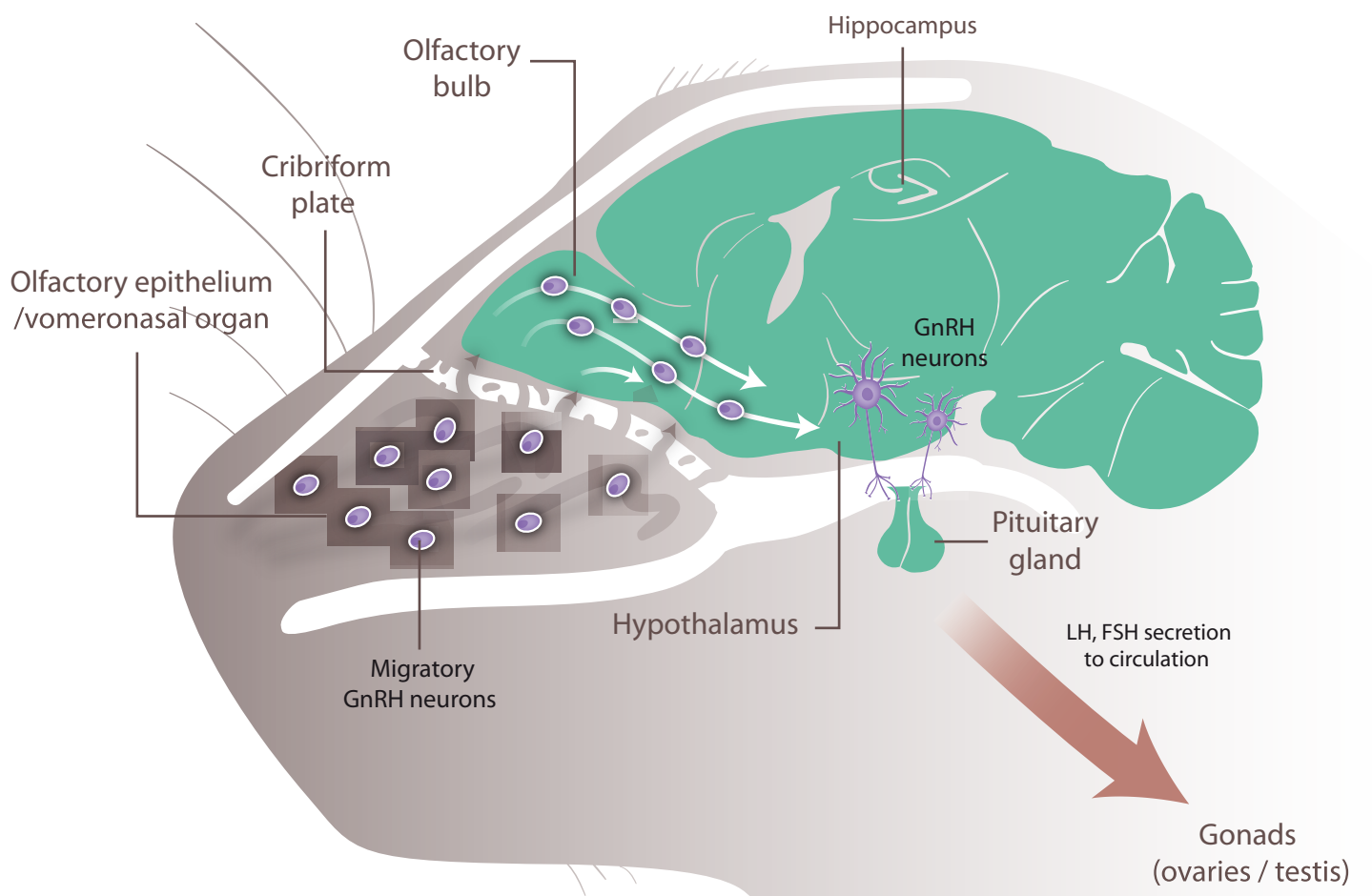

Fig. 2. TAM signaling and GnRH neuronal migration. Gonadotropin-releasing hormone (GnRH) neurons are born in the olfactory placode and epithelium / vomeronasal organ. Nascent GnRH neurons migrate along the vomeronasal/olfactory nerve into the olfactory bulb through perforations at the cribiform plate. Afterentering the forebrain, GnRH neurons change their migratory trajectory and turn caudally, continue migration until they reach their final destination at the hypothalamic region. GnRH neurons release GnRH through their extended projections to the portal system of the pituitary gland, where they regulate secretion of luteinizing hormone $(\mathrm{LH})$ and follicle-stimulating hormone (FSH) into the circulation. GAS6 supports GnRH neuronal survival through $A X L$ and TYRO3, which are expressed

by migratory GnRH neurons. Mertk expression is upregulated in post-migratory GnRH neurons. Increased apoptosis and delayed migration with a reduction in GnRH neurons reaching their final destination is seen in Tyro3-- Axl-- double knockout mice (Pierce et. al., 2008). 


\section{TAM receptor function in the developing nervous system}

Among TAM receptors, TYRO3 is most prominently expressed in the nervous system, both during development and throughout adulthood. An extensive analysis of TAM receptor expression was performed in the rat developing brain, where TYRO3 expression was found to be relatively highly expressed in the periventricular neuroepithelial layers (subventricular zones) along the forebrain, midbrain and hindbrain regions, in the nasal olfactory epithelium and along the developing spinal cord (Prieto et al., 2000). These brain regions are areas where active proliferation takes place during embryonic brain development and in a more restricted manner in neurogenic niches during adulthood (Zhao etal., 2008). The complex regulation of neural stem cell (NSC) biology involves cellular and environmental factors, and is a multi-step process, where NSCs have several binary choice points. For example, stem cells are either quiescent or proliferating. Quiescent stem cells engage in proliferation upon internal or external signals. Once proliferating, stem cells divide to produce more stem cells, thus maintaining the stem cell pool through a process of self-renewal, while otherdaughter cells engage in differentiation. The differentiating cell again faces a binary fate choice, as it can adopt a neural or glial fate. Thus, the balance between quiescence and proliferation; self-renewal or differentiation and final fate acquisition play important roles in tissue homeostasis, and are regulated by complex molecular cues (Mu et al., 2010).

In a transcriptomic screen Wang et. al. identified all three TAM receptors, and the ligand Pros 1 to be differentially enriched among neural stem/progenitor cells in the developing (E15.5) mouse cortex (Wang et al., 2011). Indeed, AXL immune-expression was confined to the cortical ventricular zone at E15.5, where active proliferation takes place. Neutralization of $A x /$ by in-utero electroporation of a dominant negative $A x /$ construct caused cortical ventricular zone neural stem/progenitor cells to prematurely differentiate, and engage in migration towards the cortical plate. This premature differentiation was accompanied by an increase in the expression of the neuronal marker $\beta$ III-tubulin and a concomitant loss of the progenitor cell markers nestin, Pax6 and Tbr2 (Wang et al., 2011). Analysis of BrdU labeling together with Ki67 immunoreactivity in cortices from $\mathrm{AxI}^{--/} ; \mathrm{Mer}^{--\alpha} \mathrm{DKO}$ also revealed the early exit of progenitor cells from the cell cycle and premature differentiation. Together, these results identified a role for TAM signaling in the maintenance of cortical embryonic neural progenitor cells.

Analysis of TAM triple knockout stem cells isolated from neonatal mouse forebrains supports a role for TAM receptors in maintaining neural progenitor identity, as well as providing trophic support for these cells (Ji et al., 2014). When cultured, TAM triple knockout neural stem/progenitor cells expressed less nerve growth factor (NGF) and brain-derived neurotrophic factor (BDNF) than control cells, suggesting trophic factor expression is regulated by TAM signaling. With respect to cell differentiation, while no effect was observed on glial daughter cell fate, a decrease in neuronal differentiation was observed in knockout cultured NSCs, suggesting TAM receptor signaling may be instructive for the acquisition of neuronal cell fates. However, deletion of all three TAM receptors was detrimental for in vitro culturing of neural stem/progenitor cells, which showed delayed growth profiles and elevated apoptotic rates compared to wild type cells (Ji et al., 2014). Investigating the differential impact of each TAM receptor on NSC biology in vivo would be of great interest, but is currently hampered by the lack of genetic tools to selectively ablate TAM receptor expression within specific neurogenic cellular compartments. Thus, understanding the relative roles of Tyro3, Axl and Mertk specifically within NSCs versus other neurogenic niche brain cells such as microglia, endothelial cells and astrocytes is not yet possible in vivo. The recent generation of a mouse harboring a conditional Mertk allele (Fourgeaud et al., 2016) would allow dissecting the relative role of Mertk in the developing nervous system.

In the adult, the postnatal ongoing generation of newborn neurons and glia from NSCs is critical for maintaining brain homeostasis and function. In rodents, NSCs residing in the subventricular zone (SVZ) provide newly generated neurons which migrate through the rostro-migratory stream and finally incorporate into the olfactory bulb. Neural stem cells residing in the subgranular hippocampal layer (SGZ) give rise to neurons which contribute to learning and memory (Deng et al., 2010; Shors et al., 2001). Adult murine SVZ neural stem/progenitor cells were shown to express all three TAM receptors and both ligands PROS1 and GAS6 (Gely-Pernot et al., 2012). Gely-Pernot et. al. inspected the role of the TAM ligands GAS6 and PROS1 on adult SVZneurogenesis. Cultured SVZneural stem/progenitor cells isolated from GAS6 $^{-/}$mice showed reduced numbers of proliferating neural stem/progenitor cells compared to wild type control cells, and generated less self-renewing neurospheres, suggesting either impaired NSC proliferation, a reduction of the NSC pool, reduced self-renewal capacity, or a combination thereof. By contrast, antibody neutralization of PROS1 increased SVZ neural stem/progenitor cell proliferation in vivo, suggesting PROS1 is inhibitory for SVZ NSC proliferation in vivo, and counteracts GAS6 function (Gely-Pernot et al., 2012).

The expression of TYRO3, MERTK, GAS6 and PROS1 in brain tissue is not confined to NSC/NPCs. Other cell types in the neurogenic niche which are known to influence neurogenesis, such as endothelial cells, microglia and astrocytes also express these TAM signaling components at steady state, and under inflammatory conditions. Thus, TAMs may influence NSC/NPC developmental processes in a NSC/NPC autonomous manner (which can be either autocrine or paracrine), or by an inter-cellular interaction, involving non- NSC/NPC cell types. For example, microglia regulate neurogenesis by secreting factors that affect different phases of the neurogenic process (Gemma et al., 2013; Sato, 2015; Sierra et al., 2014) and are also active in clearing of apoptotic newborn cells that are aborted during neurogenesis (Sierra et al., 2010). Microglia also regulate neurogenesis under inflammatory conditions. Their polarized reaction to inflammation can lead either to a neuro-protective reaction positively supporting de-novoneurogenesis, or to the suppression of neurogenesis (Belarbi et al., 2013).

Exclusive of Tyro3, allTAM signaling components are expressed by microglia (Butovsky et al., 2014; Grommes et al., 2008; Ji et al., 2013), where they mediate anti-inflammatory immune signaling and phagocytosis (Grommes et al., 2008). A recent work by Fourgeaud and colleagues showed that Mertk and Axl mediate the in vivo engulfment of apoptotic newborn neurons in the adult SVZ by microglia (Fourgeaud et al., 2016), and that both ligands PROS1 and GAS6 function in vitro as MER agonists for this phagocytic event. Thus, TAM signaling contributes to the successful and productive process of adult neurogenesis by regulating the clearance of apoptotic newborn neurons. However, as mentioned above, the polarized response of microglia can also negatively 
influence adult neurogenesis, through an elevated inflammatory response. Ji et. al. investigated microglia from TAM triple KO mice, and found they were characterized by a hyperactivated, proinflammatory cytokine profile in response to stimulation with LPS, CpG or poly(I:C) (Ji et al., 2013). This hyper-inflammatory profile of microglia was neurotoxic and detrimental to adult neurogenesis both in vitro and in vivo. Elevated microglial IL-6 secretion was a key player in this effect, as knockout of the IL-6 gene in TAM triple KO mice restored hippocampal NSC/NPC proliferation and neurogenesis, as measured by newborn $\mathrm{DCX}^{+}$neurons (Ji et al., 2013). Similar to microglia, $\mathrm{TAM}^{-/-}$astrocytes also secreted higher pro-inflammatory cytokines following stimulation by LPS, hampering NSC/NPC proliferation and the generation of newborn DCX+ neurons. Thus, microglia and astrocytes provide another facet by which TAM signaling modulates neurogenesis in a non NSC/NPC autonomous manner.

Taken together, TAM signaling plays a role in NSC/NPC proliferation and differentiation choice points during embryonic and postnatal neural development. While the role of TAM signaling in developmental and non-developmental processes builds upon investigating mice in which TAM receptors or GAS6 gene function was inactivated, very little is known about the role of PROS1 in this process. We recently conditionally ablated Pros 1 expression in neural stem/progenitor cells to investigate the relative contribution of PROS1 in stem/progenitor proliferation and differentiation. Active research is directed to better understand the role of PROS1 in neural stem/progenitor endogenous mechanisms and in niche cells. During the writing of this review, our group has published two studies identifying PROS1 as a multilevel regulator of NSC biology at the binary choice points of quiescence/ proliferation and self-renewal/differentiation, also impacting daughter cell fate. (Zelentsova et al., 2017; Zelentsova-Levitskyi et al ., 2017). It is possible that activation of TAMs by the different ligands may elicit diverse downstream signaling pathways, differentially affecting different choice points along the neurogenic process.

\section{TAM receptor function in the developing immune system}

Most of the current knowledge on TAM signaling in the immune system is focused at the functional level. Adult mice lacking all three TAM receptors were first observed to develop chronic inflammation and autoimmunity, with constitutively activated macrophages (Camenisch et al., 1999; Lemke et al., 2003; Lu, Lemke, 2001). Further studies identified TAMs are pleiotropic negative regulators of innate immunity, attenuating the immune response in Dendritic cells (DCs) (Rothlin et al., 2007). More recently, it was shown that T cell-derived PROS1 restrains DC activation via TAMs, revealing TAM function at the regulatory interface of the adoptive and innate immune arms (Carrera Silva et al., 2013). These roles of TAMs were recently extensively reviewed by Rothlin and colleagues (Rothlin et al., 2015). The involvement of TAMs in the development and maturation of immune cells is described below.

To date, TAMs were found to govern the development and maturation of natural killer (NK) cells, erythrocytes, and Langerhans cells (LC). The differentiation and maturation of committed NK progenitors involves the sequential and graduate acquisition and expression of functional surface markers and receptors, while the expression of other markers are downregulated. These processes are initiated in the bone marrow and are driven by signals provided by bone marrow stromal cells. Roth and colleagues have shown that all three TAM receptors contribute to the development and maturation of NK cells (Caraux et al., 2006). They have shown that all three TAM receptors are expressed by NK cells, and that TAM expression on NKs is critical in the formation of the full NK cell repertoire, including their functional maturation. Additionally, recombinant GAS6 and PROS1 promoted the growth and differentiation of NK precursors in vitro, indicating functional ligand-receptor interaction drives this process (Caraux et al., 2006). These results suggest that bone marrow stromal cells which express both GAS6 and PROS1 are likely to drive TAM-dependent NK differentiation in vivo. The analysis of NK cell repertoire and maturation in Gas6 null mice will likely contribute to understanding the role of GAS6 in NK cell ontogeny. Similarly, using a stromal-specific cre-mediated deletion of Pros 1 is necessary to verify and positively identify a role for PROS1 in vivo.

Erythropoiesis - the generation of oxygen carrying red blood cells - from hematopoietic stem cells was shown to be regulated by GAS6 and AXL (Angelillo-Scherrer et al., 2008; Tang et al., 2009 ). With an average life span of 40 days in mice, the bone marrow and spleen are the major sites of ongoing erythropoiesis from hematopoietic stem cells (HSCs) in adult mice (Green, 1966). Angelillo-Sherrer and colleagues studied erythropoiesis in Gas6 $^{-\alpha}$ mice, and found a significant reduction in numbers of erythroid progenitors (both burst-forming unit-erythroid (BFU-E) and colony-forming unit-erythroid (CFU-E) in fetal liver and adult bone marrow. GAS6 expression by erythroblasts is induced by Erythropoietin (Epo), and this effect is AXL-dependent. GAS6 enhanced erythroblast cell survival and Epo downstream signaling, and suppressed cytokine signaling known to inhibit erythropoiesis (Angelillo-Scherrer et al., 2008). Another study identified the expression of the erythropoiesis-related genes GATA-1 and Epo-R to be regulated by AXL and MER (Tang et al., 2009).

It is interesting to compare the different expression patterns of TAM receptors and ligands between differentiating NK cells and erythrocytes with those of differentiating NSCs. Both immune and neural precursor populations reside within their specific niche, where they intimately interact with non-precursor niche cells, also expressing TAM signaling components. However, while NSC/NPCs and erythroblasts express both TAM receptors and at least one ligand, NK precursor cells express TAM receptors, while ligands are predominantly expressed by the stromal cells of their niche. This may underlie fundamental differences in maturation, differentiation and specification between both developmental systems, reflecting altered autonomous and non-autonomous TAM mechanisms. More broadly within the hematopoietic stem cell niche, TAM signaling components are expressed by hematopoietic stem cells and bone marrow stromal cells (Avanzi et al., 1997; Graham et al., 1994; Satomura et al., 1998) and GAS6 was shown to support hematopoiesis in vitro (Dormady et al., 2000). Thus, various aspects of hematopoiesis and erythropoiesis are regulated by TAM signaling.

Another immune cell population whose development and differentiation was shown to be TAM-driven are Langerhans cells (LCs). LCs comprise a subset of myeloid-derived dendritic cells which reside within the skin epidermis. LCs represent the exclusive antigen-presenting cells in this peripheral tissue, and regulate skin immune responses against pathogens, environmental insult and stress (Ginhoux et al., 2010). LCs are derived from embryonic hematopoietic precursors, which populate the skin at late embryo- 
genesis. In the adult, under steady state conditions epidermal LCs leave the skin and migrate to draining lymph nodes, whereas new LCs repopulate the skin either from circulating monocytes, or by local proliferation. Under acute inflammatory conditions, LCs are repopulated by circulating precursors, mainly blood monocytes (Ginhoux, Merad, 2010).

TGF- $\beta$ is a key regulator of LC development and maintenance, as TGF- $\beta$ deficient mice lack DCs, (Borkowski et al., 1996) and the conditional ablation of TGF- $\beta$ receptor 1 in adult DCs results in their premature spontaneous maturation, indicating its importance in maintaining a pool of immature LCs in the epidermis (Kel et al., 2010). In a recent report, Bauer and colleagues identified AXL to be a key effector of TGF- $\beta 1$ during LC cell differentiation (Bauer et al., 2012). Using a defined in vitro serum-free LC differentiation model, they have found that $A X L$ transcript expression is induced during the early phases of human LC commitment, and that $A X L$ expression was dependent on TGF- $\beta 1$ induction. Similarly, TGF- $\beta 1$ stimulated $A X L$ expression in mouse bone marrow-derived DCs (BMDCs). Moreover, LC subsets in which AXL expression was upregulated showed an elevated differentiation potential compared to AXL-negative subsets. Of note, the diminution of $50 \%$ of LC cells in mice was observed only in TAM triple KO mice, as inactivation of $A x l$ alone in mice did not result in diminution of LC numbers, which was only observed in human cells (Bauer et al., 2012). This difference observed between human and murine LCs may be due to functional redundancy in mice. Alternatively, it may suggest that TAM signaling may be important for the maintenance of LCs in the epidermis. Understanding these differences requires further investigation.

Importantly, since AXL induction occurs in activated dendritic cells downstream of TLR signaling (Rothlin et al., 2007), Bauer et. al. have also made the distinction between $A X L$ activation during NK differentiation versus following TLR stimulation. Interestingly, TLR-mediated AXL induction occurs in the presence of TGF- $\beta$ inhibitors, indicating context-specific and independent pathways for AXL activation in LCs. Finally, the ability of TGF- $\beta$ to independently regulate all three TAM receptors in DCs and LCs (Bauer et al., 2012; Rothlin et al., 2007) is supported by immuno-histochemical staining which revealed the abundant expression of both GAS6 and PROS1 in human epidermis (Bauer et al., 2012).

\section{TAM receptor function in the developing vasculature}

Expression of $A x l$ and Mertk, as well as both ligands Pros 1 and Gas 6 by endothelial cells (ECs) and vascular smooth muscle cells (VSMCs) is well documented (Benzakour et al., 1995; Benzakour et al., 2000; Burstyn-Cohen et al., 2009; Fair et al., 1986; Stitt et al., 1995). In the adult, TAMs regulate various aspects of vascular biology, including vessel integrity (Burstyn-Cohen et al., 2009; Miner et al., 2015; Zhu et al., 2010), and vascular remodeling in response to injury (Korshunov et al., 2006).

The expression of TAMs by ECs and VSMCs suggests they may also be instructive in formation of new blood vessels, both in health and in disease. Inhibition of AXL in primary human endothelial cells impaired blood vessel formation both in vitro and in vivo, suggesting possible clinical implications not only during developmental processes, but also in cancer settings (Holland et al., 2010; Holland et al., 2005). Endothelial cell motility is a necessary step in blood vessel formation, another aspect of angiogenesis where $A X L$ was shown to mediate VEGF-A-induced EC migration, through Akt activation (Ruan et al., 2012). Thus, AXL seems to mediate both migration and tube formation of endothelial cells. The regulation of angiogenesis is a highly complex and coordinated process, involving molecular and cellular mechanisms, to ensure an overall balanced process, and importantly to avoid the aberrant or over-production of blood vessels. In this respect GAS6/AXL and PROS1/MERTK signaling were reported to inhibit VEGF-A-induced chemotaxis and tube formation of ECs (Fraineau et al., 2012; Gallicchio et al., 2005), suggesting TAM signaling may elicit both pro-and anti-angiogenic effects, contributing to an overall tightly regulated process. Interestingly, the inhibitory effect of both pathways was dependent on the tyrosine phosphatase SHP2.

With respect to TAM ligands - both ligands PROS1 and GAS6 promote survival of ECs and VSMCs (Burstyn-Cohen et al., 2009; Gasic et al., 1992; Healy et al., 2001; Melaragno et al., 2004; O'Donnell et al., 1999). Gas6-/- mice are not reported to have abnormal angiogenesis (Angelillo-Scherrer et al., 2001), albeit we have previously shown that Gas 6 null mice have compromised blood vessel integrity, as do $\mathrm{Axt}^{/-}$mice, but not $\mathrm{Tyro3}^{-/-}$or $\mathrm{Mertk}^{{ }^{-}}$mice (Burstyn-Cohen et al., 2009).

We previously reported a role for PROS1 in angiogenesis. Pros $^{-1-}$ mice die embryonically between days E15.5-E17.5 from massive coagulopathy with associated hemorrhages, blood clots and defective blood vessel formation (Burstyn-Cohen et al., 2009). At E13.5, prior to coagulation defects, Pros 1/- mice showed defects in blood vessel development and integrity not only in embryonic tissue per-se, but also in the extra-embryonic vasculature of the yolk sac. Endothelial cells in Pros $1^{-/}$mice presented with an activated morphology and aggregated in clusters but did not form tubular vessel structures, indicating an in vivo role for Pros1 in angiogenesis. Consistent with Pros 1 being a mitogen for VSMCs (Gasic et al., 1992), we found fewer VSMCs supporting blood vessels in Pros $1^{-/}$embryos. The few VSMCs that were found associated to nascent blood vessels did not form a supportive ring around the developing vasculature, leading to collapse of blood vessels. Interestingly, vascular development following the conditional knockout of Pros1 from ECs (using the Tie2-cre) was not grossly affected, whereas deletion of Pros 1 from the VSMC cellular compartment (with SM22-Cre) led to leaky vasculature (Burstyn-Cohen et al., 2009).

Finally, the bioactivity of PROS1 and GAS6 requires the vitamin K-dependent gamma-carboxylation of glutamate residues residing in the amino-terminal Gla domain (Fig. 1) (Lew et al., 2014; Stitt et al., 1995). Vitamin K epoxide reductase (VKOR) catalyzes the epoxide of vitamin $\mathrm{K}$ back to vitamin $\mathrm{K}$, and is predominantly expressed in the vascular system. Studying the vitamin K pathway and its relation to angiogenesis can therefore highlight the importance of vitamin K-dependent proteins including PROS1 and GAS6 in angiogenesis, especially in light of the fact that warfarin which inhibits VKOR enzymatic activity by direct interaction (Tie et al., 2008 ) is still the most commonly prescribed oral anticoagulant. The relevance of VKOR to the angiogenic process was demonstrated following stimulation and inhibition experiments. Overexpression of VKOR in human primary endothelial cells stimulated their proliferation, migration and tubular network formation, while VKOR knockdown inhibited EC tube formation (Wang et al., 2005), further supporting the importance of this biochemical pathway. Moreover, a recent study identified the UBIAD-vitamin K2 gene to underlie 
the cranial hemorrhages and defective EC survival during early vascular development, leading to vascular degeneration in the zebrafish mutant reddish (Hegarty et al., 2013). Taken together, TAMs clearly play a role in vascular development and in angiogenesis, both in health and in disease. The relative roles of the different TAM signaling components remain to be revealed. Similarly, what are the relative contributions of PROS1 and GAS6 in ECs versus VSMCs? What downstream signaling and cellular events are induced by each possible receptor-ligand interaction, and how are these regulated? Answering these questions may provide a platform for the development of therapeutic manipulation for treatment of vascular diseases, or for controlling unrestrained angiogenesis as seen in cancer and wet age-related macular degeneration (AMD).

\section{Concluding remarks}

As mentioned above, inactivation of TAM receptors and/or ligands leads to developmental deficits in various tissues. The regulation of cell survival, proliferation, and migration by TAMs in tumor cells is mirrored in development, as seen for GnRH neurons, NSC/NPC populations and endothelial cells. TAM signaling also seems to play a role in cell differentiation processes, as seen for erythrocytes and natural killer cells, neural stem/precursor cells and in maturation of germ cells. These processes most likely involve interactions between precursor cell populations and their niche cells. Similar interactions are thought to occur between cancer stem cells and their environment, which may induce their exit from dormancy. In this respect, GAS6 and MERTK were shown to regulate prostate cancer stem cell dormancy and survival in the bone marrow (Jung et al., 2016; Shiozawa et al., 2010).

The abundant expression of TAM signaling components not only by the cells they affect but also within neighboring cells, together with the fact that PROS1 and GAS6 are secreted molecules, encumbers analysis of receptor-ligand inter-cellular cross-talk, and urges the generation of experimental tools (such as conditional knockout mice) for Tyro3, Axl and Gas6 to precisely target TAM molecules in specific cell populations. The generation of such tools is expected to better elucidate the specific roles and mechanisms by which TAM signaling components impact numerous systems and processes during development and throughout adulthood.

\section{References}

ALLEN, M.P., ZENG, C., SCHNEIDER, K., XIONG, X., MEINTZER, M.K., BELLOSTA, P., BASILICO, C., VARNUM, B., HEIDENREICH, K.A. and WIERMAN, M.E. (1999). Growth Arrest-Specific Gene 6 (Gas6)/Adhesion Related Kinase (Ark) Signaling Promotes Gonadotropin-Releasing Hormone Neuronal Survival via Extracellular Signal-Regulated Kinase (ERK) and Akt. Molec. Endocrinol. 13: 191-201.

ANDERSON, H.A., MAYLOCK, C.A., WILLIAMS, J.A., PAWELETZ, C.P., SHU, H. and SHACTER, E. (2003). Serum-derived protein $S$ binds to phosphatidylserine and stimulates the phagocytosis of apoptotic cells. Nat Immunol 4: 87-91.

ANGELILLO-SCHERRER, A., BURNIER, L., FLORES, N., SAVI, P., DEMOL, M., SCHAEFFER, P., HERBERT, J.M., LEMKE, G., GOFF, S.P., MATSUSHIMA, G.K. et al., (2005). Role of Gas6 receptors in platelet signaling during thrombus stabilization and implications for antithrombotic therapy. J Clin Invest 115:237-246.

ANGELILLO-SCHERRER, A., BURNIER, L., LAMBRECHTS, D., FISH, R.J., TJWA, M., PLAISANCE, S., SUGAMELE, R., DEMOL, M., MARTINEZ-SORIA, E., MAXWELL, P.H. et al., (2008). Role of Gas6 in erythropoiesis and anemia in mice. J. Clin. Invest. 118: 583-596.

ANGELILLO-SCHERRER, A., DE FRUTOS, P., APARICIO, C., MELIS, E., SAVI, P., LUPU, F., ARNOUT, J., DEWERCHIN, M., HOYLAERTS, M., HERBERT, J. et al.,
(2001). Deficiency or inhibition of Gas6 causes platelet dysfunction and protects mice against thrombosis. Nat Med 7: 215-221.

AVANZI, G.C., GALLICCHIO, M., CAVALLONI, G., GAMMAITONI, L., LEONE, F., ROSINA, A., BOLDORINI, R., MONGA, G., PEGORARO, L., VARNUM, B. et al., (1997). GAS6, the ligand of Axl and Rse receptors, is expressed in hematopoietic tissue but lacks mitogenic activity. Exp. Hematol 25: 1219-1226.

AXELROD, H. and PIENTA, K.J. (2014). Axl as a mediator of cellular growth and survival. Oncotarget. 5: 8818-8852.

BAUER, T., ZAGÓRSKA, A., JURKIN, J., YASMIN, N., KÖFFEL, R., RICHTER, S., GESSLBAUER, B., LEMKE, G. and STROBL, H. (2012). Identification of Ax as a downstream effector of TGF- $\beta 1$ during Langerhans cell differentiation and epidermal homeostasis. J. Exp. Med. 209: 2033-2047.

BELARBI, K. and ROSI, S. (2013). Modulation of adult-born neurons in the inflamed hippocampus. Front. Cell. Neurosci. 7:145; doi: 10.3389/fncel.2013.00145

BENZAKOUR, O., FORMSTONE, C., RAHMAN, S., KANTHOU, C., DENNEHY, U., SCULLY, M.F., KAKKAR, V.V. and D N COOPER, D.N. (1995). Evidence for a protein $S$ receptor(s) on human vascular smooth muscle cells. Analysis of the binding characteristics and mitogenic properties of protein $S$ on human vascular smooth muscle cells. Biochem J 308: 481-485.

BENZAKOUR, O. and KANTHOU, C. (2000). The anticoagulant factor, protein S, is produced by cultured human vascular smooth muscle cells and its expression is up-regulated by thrombin. Blood 95: 2008-2014.

BORKOWSKI, T.A., LETTERIO, J.J., FARR, A.G. and UDEY, M.C. (1996). A Role for Endogenous Transforming Growth Factor $\beta 1$ in Langerhans Cell Biology: The Skin of Transforming Growth Factor $\beta 1$ Null Mice Is Devoid of Epidermal Langerhans Cells. J. Exp. Med. 184: 2417-2422.

BRAND, T.M., IIDA, M., STEIN, A.P., CORRIGAN, K.L., BRAVERMAN, C.M., LUTHAR, N., TOULANY, M., GILL, P.S., SALGIA, R., KIMPLE, R.J. et al., (2014). AXL Mediates Resistance to Cetuximab Therapy. Cancer Res. 74: 5152-5164.

BURSTYN-COHEN, T., HEEB, M.J. and LEMKE, G. (2009). Lack of Protein $S$ in mice causes embryonic lethal coagulopathy and vascular dysgenesis. $J$ Clin Invest 119: 2942-2953

BURSTYN-COHEN, T., LEW, E.D., TRAVES, P.G., BURROLA, P.G., HASH, J.C. and LEMKE, G. (2012). Genetic dissection of TAM receptor-ligand interaction in retinal pigment epithelial cell phagocytosis. Neuron 76: 1123-1132.

BUTOVSKY, O., JEDRYCHOWSKI, M.P., MOORE, C.S., CIALIC, R., LANSER, A.J. GABRIELY, G., KOEGLSPERGER, T., DAKE, B., WU, P.M., DOYKAN, C.E. et al., (2014). Identification of a unique TGF-[beta]-dependent molecular and functional signature in microglia. Nature Neurosci. 17: 131-143.

CAMENISCH, T.D., KOLLER, B.H., EARP, H.S. and MATSUSHIMA, G.K. (1999). A novel receptor tyrosine kinase, Mer, inhibits TNF-alpha production and lipopolysaccharide-induced endotoxic shock. J Immunol 162: 3498-3503.

CARAUX, A., LU, Q., FERNANDEZ, N., RIOU, S., DI SANTO, J.P., RAULET, D.H., LEMKE, G. and ROTH, C. (2006). Natural killer cell differentiation driven by Tyro3 receptor tyrosine kinases. Nat Immunol 7: 747-754.

CARRERA SILVA, E.A., CHAN, P.Y., JOANNAS, L., ERRASTI, A.E., GAGLIANI, N., BOSURGI, L., JABBOUR, M., PERRY, A., SMITH-CHAKMAKOVA, F., MUCIDA, D. et al., (2013). T cell-derived protein S engages TAM receptor signaling in dendritic cells to control the magnitude of the immune response. Immunity 39: 160-170.

CHEN, J., CAREY, K. and GODOWSKI, P.J. (1997). Identification of Gas6 as a ligand for Mer, a neural cell adhesion molecule related receptor tyrosine kinase implicated in cellular transformation. Oncogene 14: 2033-2039.

CHEN, Y., WANG, H., QI, N., WU, H., XIONG, W., MA, J., LU, Q. and HAN, D. (2009). Functions of TAM RTKs in regulating spermatogenesis and male fertility in mice. Reproduction 138: 655-666.

COOL, J., DEFALCO, T. and CAPEL, B. (2012). Testis formation in the fetal mouse: dynamic and complex de novo tubulogenesis. Wiley Interdisciplinary Reviews: Dev. Biol. 1: 847-859.

CROSIER, P.S., LEWIS, P.M., HALL, L.R., VITAS, M.R., MORRIS, C.M., BEIER, D.R., WOOD, C.R. and CROSIER, K.E. (1994). Isolation of a receptor tyrosine kinase (DTK) from embryonic stem cells: structure, genetic mapping and analysis of expression. Growth Factors 11: 125-136.

CUMMINGS, C.T., DERYCKERE, D., EARP, H.S. and GRAHAM, D.K. (2013). Molecular pathways: MERTK signaling in cancer. Clin. Cancer Res. 19: 5275-5280.

D'CRUZ, P.M., YASUMURA, D., WEIR, J., MATTHES, M.T., ABDERRAHIM, H., LAVAIL, M.M. and VOLLRATH, D. (2000). Mutation of the receptor tyrosine kinase gene 
Mertk in the retinal dystrophic RCS rat. Hum Mol Genet 9: 645-651.

DENG, W., AIMONE, J.B. and GAGE, F.H. (2010). New neurons and new memories: how does adult hippocampal neurogenesis affect learning and memory? Nature Rev. Neurosci. 11: 339-350.

DORMADY, S.P., ZHANG, X.-M. and BASCH, R.S. (2000). Hematopoietic progenitor cells grow on $3 \mathrm{~T} 3$ fibroblast monolayers that overexpress growth arrest-specific gene-6 (GAS6). Proc. Natl. Acad. Sci. USA 97: 12260-12265.

DUNCAN, J.L., LAVAIL, M.M., YASUMURA, D., MATTHES, M.T., YANG, H., TRAUTMANN, N., CHAPPELOW, A.V., FENG, W., EARP, H.S., MATSUSHIMA, G.K. et al., (2003). An RCS-Like Retinal Dystrophy Phenotype in Mer Knockout Mice. Invest Ophthalmol Vis Sci 44: 826-838.

ELKABETS, M., PAZARENTZOS, E., JURIC, D., SHENG, Q., PELOSSOF, R.A., BROOK, S., BENZAKEN, A.O., RODON, J., MORSE, N., YAN, J.J. et al., (2015). AXL mediates resistance to PI3Kalpha inhibition by activating the EGFR/PKC/ mTOR axis in head and neck and esophageal squamous cell carcinomas. Cancer Cell 27: 533-546.

ELLIOTT, M.R. and RAVICHANDRAN, K.S. (2010). Clearance of apoptotic cells: implications in health and disease. J Cell Biol 189: 1059-1070.

FAIR, D.S., MARLAR, R.A. and LEVIN, E.G. (1986). Human endothelial cells synthesize protein S. Blood 67: 1168-1171.

FANG, Z., XIONG, X., JAMES, A., GORDON, D.F. and WIERMAN, M.E. (1998). Identification of Novel Factors That Regulate GnRH Gene Expression and Neuronal Migration. Endocrinology 139: 3654-3657.

FOURGEAUD, L., TRAVÉS, P.G., TUFAIL, Y., LEAL-BAILEY, H., LEW, E.D., BURROLA, P.G., CALLAWAY, P., ZAGÓRSKA, A., ROTHLIN, C.V., NIMMERJAHN, A. et al., (2016). TAM receptors regulate multiple features of microglial physiology. Nature 532: 240-244.

FRAINEAU, S., MONVOISIN, A., CLARHAUT, J., TALBOT, J., SIMONNEAU, C., KANTHOU, C., KANSE, S.M., PHILIPPE, M. and BENZAKOUR, O. (2012). The vitamin $\mathrm{K}$-dependent anticoagulant factor, protein $\mathrm{S}$, inhibits multiple VEGF-Ainduced angiogenesis events in a Mer- and SHP2-dependent manner. Blood 120: 5073-5083.

GALLICCHIO, M., MITOLA, S., VALDEMBRI, D., FANTOZZI, R., VARNUM, B., AVANZI, G.C. and BUSSOLINO, F. (2005). Inhibition of vascular endothelial growth factor receptor 2-mediated endothelial cell activation by Axl tyrosine kinase receptor. Blood 105: 1970-1976.

GASIC, G.P., ARENAS, C.P., GASIC, T.B. and GASIC, G.J. (1992). Coagulation factors $\mathrm{X}, \mathrm{Xa}$, and protein $\mathrm{S}$ as potent mitogens of cultured aortic smooth muscle cells. Proc. Natl. Acad. Sci. USA 89: 2317-2320.

GELY-PERNOT, A., CORONAS, V., HARNOIS, T., PRESTOZ, L., MANDAIRON, N., DIDIER, A., BERJEAUD, J.M., MONVOISIN, A., BOURMEYSTER, N., DE FRUTOS, P.G. et al., (2012). An endogenous vitamin K-dependent mechanism regulates cell proliferation in the brain subventricular stem cell niche. Stem Cells 30: 719-731.

GEMMA, C. and BACHSTETTER, A.D. (2013). The role of microglia in adult hippocampus neurogenesis. Front. Cell. Neurosci.7:229; doi: 10.3389/fncel.2013.00229

GINHOUX, F. and MERAD, M. (2010). Ontogeny and homeostasis of Langerhans cells. Immunol Cell Biol 88: 387-392.

GODOWSKI, P.J., MARK, M.R., CHEN, J., SADICK, M.D., RAAB, H. and HAMMONDS, R.G. (1995). Reevaluation of the roles of protein $S$ and Gas6 as ligands for the receptor tyrosine kinase Rse/Tyro 3. Cell 82: 355-358.

GRAHAM, D., DAWSON, T., MULLANEY, D., SNODGRASS, H. and EARP, H. (1994). Cloning and mRNA expression analysis of a novel human protooncogene, cmer [published erratum appears in Cell Growth Differ 1994 Sep;5(9):1022]. Cell Growth Differ 5: 647-657.

GRAHAM, D.K., DERYCKERE, D., DAVIES, K.D. and EARP, H.S. (2014). The TAM family: phosphatidylserine-sensing receptor tyrosine kinases gone awry in cancer. Nature Rev. Cancer 14: 769-785.

GREEN E.W. (Ed.) (1966). Biology of the laboratory mouse. Dover publications inc., New York.

GROMMES, C., LEE, C.Y., WILKINSON, B.L., JIANG, Q., KOENIGSKNECHT-TALBOO, J.L., VARNUM, B. and LANDRETH, G.E. (2008). Regulation of microglial phagocytosis and inflammatory gene expression by Gas6 acting on the Axl/Mer family of tyrosine kinases. J Neuroimmune Pharmacol 3: 130-140.

HALL, M.O., OBIN, M.S., HEEB, M.J., BURGESS, B.L. and ABRAMS, T.A. (2005). Both protein $S$ and Gas6 stimulate outer segment phagocytosis by cultured rat retinal pigment epithelial cells. Exp Eye Res 81: 581-591.

HALL, M.O., PRIETO, A.L., OBIN, M.S., ABRAMS, T.A., BURGESS, B.L., HEEB, M.J. and AGNEW, B.J. (2001). Outer segment phagocytosis by cultured retinal pigment epithelial cells requires Gas6. Exp Eye Res 73: 509-520.

HEALY, A.M., SCHWARTZ, J.J., ZHU, X., HERRICK, B.E., VARNUM, B. and FARBER, H.W. (2001). Gas 6 promotes Axl-mediated survival in pulmonary endothelial cells. Am. J. Physiol - Lung Cell. Molec. Physiol. 280: L1273-L1281.

HEGARTY, J.M., YANG, H. and CHI, N.C. (2013). UBIAD1-mediated vitamin K2 synthesis is required for vascular endothelial cell survival and development. Development 140: 1713-1719.

HERBISON, A.E. (2016). Control of puberty onset and fertility by gonadotropinreleasing hormone neurons. Nat Rev Endocrinol 12: 452-466.

HOLLAND, S.J., PAN, A., FRANCI, C., HU, Y., CHANG, B., LI, W., DUAN, M., TORNEROS, A., YU, J., HECKRODT, T.J. et al., (2010). R428, a selective small molecule inhibitor of Axl kinase, blocks tumor spread and prolongs survival in models of metastatic breast cancer. Cancer Res 70: 1544.

HOLLAND, S.J., POWELL, M.J., FRANCI, C., CHAN, E.W., FRIERA, A.M., ATCHISON, R.E., MCLAUGHLIN, J., SWIFT, S.E., PALI, E.S., YAM, G. et al., (2005). Multiple Roles for the Receptor Tyrosine Kinase Axl in Tumor Formation. Cancer Res. 65: 9294-9303.

JI, R., MENG, L., JIANG, X., CVM, N.K., DING, J., LI, Q. and LU, Q. (2014). TAM Receptors Support Neural Stem Cell Survival, Proliferation and Neuronal Differentiation. PloS one 9: e115140.

JI, R., TIAN, S., LU, H.J., LU, Q., ZHENG, Y., WANG, X., DING, J. and LI, Q. (2013). TAM receptors affect adult brain neurogenesis by negative regulation of microglial cell activation. J. Immunol. 191: 6165-6177.

JUNG, Y., DECKER, A.M., WANG, J., LEE, E., KANA, L.A., YUMOTO, K., CACKOWSKI, F.C., RHEE, J., CARMELIET, P., BUTTITTA, L. et al., (2016). Endogenous GAS6 and Mer receptor signaling regulate prostate cancer stem cells in bone marrow. Oncotarget 7: 25698 - 256711.

KEL, J.M., GIRARD-MADOUX, M.J.H., REIZIS, B. and CLAUSEN, B.E. (2010). TGF- $\beta$ Is Required To Maintain the Pool of Immature Langerhans Cells in the Epidermis. J. Immunol. 185: 3248-3255.

KORSHUNOV, V.A., MOHAN, A.M., GEORGER, M.A. and BERK, B.C. (2006). Axl, A Receptor Tyrosine Kinase, Mediates Flow-Induced Vascular Remodeling. Circ Res 98: 1446-1452.

LAI, C., GORE, M. and LEMKE, G. (1994). Structure, expression, and activity of Tyro 3, a neural adhesion-related receptor tyrosine kinase. Oncogene 9: 2567-2578.

LAI, C. and LEMKE, G. (1991). An extended family of protein-tyrosine kinase genes differentially expressed in the vertebrate nervous system. Neuron 6: 691-704.

LEMKE, G. (2013). Biology of the TAM receptors. CSH Perspec. Biol. 5: a009076.

LEMKE, G. and BURSTYN-COHEN, T. (2010). TAM receptors and the clearance of apoptotic cells. Ann. NY. Acad. Sci. 1209: 23-29.

LEMKE, G. and LU, Q. (2003). Macrophage Regulation by Tyro3 family receptors. Curr. Opin. Immunol. 15: 31-36.

LEMKE, G. and ROTHLIN, C.V. (2008). Immunobiology of the TAM receptors. Nat Rev Immunol 8: 327-336.

LEW, E.D., OH, J., BURROLA, P.G., LAX, I., ZAGÓRSKA, A., TRAVÉS, P.G., SCHELSSINGER, J. and LEMKE, G. (2014). Differential TAM receptor-ligandphospholipid interactions delimit differential TAM bioactivities. eLife 2014;3:e03385 - doi: 10.7554/eLife.03385

LU, Q., GORE, M., ZHANG, Q., CAMENISCH, T., BOAST, S., CASAGRANDA, F., LAI, C., SKINNER, M.K., KLEIN, R., MATSUSHIMA, G.K. et al., (1999). Tyro-3 family receptors are essential regulators of mammalian spermatogenesis. Nature 398: 723-728.

LU, Q. and LEMKE, G. (2001). Homeostatic regulation of the immune system by receptor tyrosine kinases of the Tyro 3 family. Science 293: 306-311.

LU, Q., LI, Q. and LU, Q. (2010). Regulation of phagocytosis by TAM receptors and their ligands. Front. Biol. 5: 227-237.

MANFIOLETTI, G., BRANCOLINI, C., AVANZI, G. and SCHNEIDER, C. (1993). The protein encoded by a growth arrest-specific gene (gas6) is a new member of the vitamin $\mathrm{K}$-dependent proteins related to protein $\mathrm{S}$, a negative coregulator in the blood coagulation cascade. Mol Cell Biol 13: 4976-4985.

MARK, M.R., CHEN, J., HAMMONDS, R.G., SADICK, M. and GODOWSK, P.J. (1996). Characterization of Gas6, a member of the superfamily of $G$ domain-containing 
proteins, as a ligand for Rse and Axl. J Biol Chem 271: 9785-9789.

MELARAGNO, M.G., CAVET, M.E., YAN, C., TAI, L.K., JIN, Z.G., HAENDELER, J. and BERK, B.C. (2004). Gas6 inhibits apoptosis in vascular smooth muscle: role of Axl kinase and Akt. J Mol Cell Cardiol 37: 881-887.

MINER, J.J., DANIELS, B.P., SHRESTHA, B., PROENCA-MODENA, J.L., LEW, E.D., LAZEAR, H.M., GORMAN, M.J., LEMKE, G., KLEIN, R.S. and DIAMOND, M.S. (2015). The TAM receptor Mertk protects against neuroinvasive viral infection by maintaining blood-brain barrier integrity. Nat Med 21: 1464-1472.

MU, Y., LEE, S.W. and GAGE, F.H. (2010). Signaling in adult neurogenesis. Curr Opin Neurobiol 20: 416-423.

NAGATA, K., OHASHI, K., NAKANO, T., ARITA, H., ZONG, C., HANAFUSA, H. and MIZUNO, K. (1996). Identification of the product of growth arrest-specific gene 6 as a common ligand for Axl, Sky, and Mer receptor tyrosine kinases. J Biol Chem 271: 30022-30027.

NAKAMURA, Y.S., HAKEDA, Y., TAKAKURA, N., KAMEDA, T., HAMAGUCHI, I., MIYAMOTO, T., KAKUDO, S., NAKANO, T., KUMEGAWA, M. and SUDA, T. (1998). Tyro 3 receptor tyrosine kinase and its ligand, Gas6, stimulate the function of osteoclasts. Stem Cells 16: 229-238.

O'BRYAN, J.P., FRYE, R.A., COGSWELL, P.C., NEUBAUER, A., KITCH, B., PROKOP, C., ESPINOSA, R., LE BEAU, M.M., EARP, H.S. and LIU, E.T. (1991). axI, a transforming gene isolated from primary human myeloid leukemia cells, encodes a novel receptor tyrosine kinase. Mol. Cell. Biol. 11: 5016-5031.

O'DONNELL, K., HARKES, I.C., DOUGHERTY, L. and WICKS, I.P. (1999). Expression of receptor tyrosine kinase Axl and its ligand Gas6 in rheumatoid arthritis: evidence for a novel endothelial cell survival pathway. Am J Pathol154:1171-1180.

OHASHI, K., NAGATA, K., TOSHIMA, J., NAKANO, T., ARITA, H., TSUDA, H., SUZUKI, K. and MIZUNO, K. (1995). Stimulation of sky receptor tyrosine kinase by the product of growth arrest-specific gene 6. J Biol Chem 270: 22681-22684.

PIERCE, A., BLIESNER, B., XU, M., NIELSEN-PREISS, S., LEMKE, G., TOBET, S. and WIERMAN, M.E. (2008). Axl and Tyro3 Modulate Female Reproduction by Influencing Gonadotropin-Releasing Hormone Neuron Survival and Migration. Molec. Endocrinol. 22: 2481-2495.

POON, I.K.H., LUCAS, C.D., ROSSI, A.G. and RAVICHANDRAN, K.S. (2014). Apoptotic cell clearance: basic biology and therapeutic potential. Nature Rev. Immunol. 14: 166-180.

PRASAD, D., ROTHLIN, C.V., BURROLA, P., BURSTYN-COHEN, T., LU, Q., GARCIA DE FRUTOS, P. and LEMKE, G. (2006). TAM receptor function in the retinal pigment epithelium. Mol Cell Neurosci 33: 96-108.

PRIETO, A.L., WEBER, J.L. and LAI, C. (2000). Expression of the receptor proteintyrosine kinases Tyro-3, Axl, and mer in the developing rat central nervous system. J Comp Neurol 425: 295-314.

REBOURCET, D., O'SHAUGHNESSY, P.J., PITETTI, J.-L., MONTEIRO, A., O'HARA, L., MILNE, L., TSAI, Y.T., CRUICKSHANKS, L., RIETHMACHER, D., GUILLOU, F. et al., (2014). Sertoli cells control peritubular myoid cell fate and support adult Leydig cell development in the prepubertal testis. Development 141: 2139-2149.

ROTHLIN, C.V., CARRERA-SILVA, E.A., BOSURGI, L. and GHOSH, S. (2015). TAM Receptor Signaling in Immune Homeostasis. Ann. Rev. Immunol. 33: 355-391.

ROTHLIN, C.V., GHOSH, S., ZUNIGA, E.I., OLDSTONE, M.B. and LEMKE, G. (2007). TAM Receptors Are Pleiotropic Inhibitors of the Innate Immune Response. Cell 131: 1124-1136.

ROTHLIN, C.V. and LEMKE, G. (2010). TAM receptor signaling and autoimmune disease. Curr Opin Immunol 22: 740-746.

RUAN, G.X. and KAZLAUSKAS, A. (2012). Axl is essential for VEGF-A-dependent activation of PI3K/Akt. EMBO J. 31: 1692-1703.

SALIAN-MEHTA, S., XU, M., PIERCE, A., BLIESNER, B., TOBET, S. and WIERMAN, M.E. (2014). Loss of Growth arrest specific gene 6 (Gas6) results in altered GnRH neuron migration, delayed vaginal opening and sexual maturation in mice. Molec. Cell. Endocrinol. 393: 164-170.

SATO, K. (2015). Effects of Microglia on Neurogenesis. Glia 63: 1394-1405.

SATOMURA, K., DERUBEIS, A.R., FEDARKO, N.S., IBARAKI-O'CONNOR, K.,
KUZNETSOV, S.A., ROWE, D.W., YOUNG, M.F. and ROBEY, P.G. (1998). Receptor tyrosine kinase expression in human bone marrow stromal cells. J. Cell. Physiol. 177: 426-438.

SCOTT, R.S., MCMAHON, E.J., POP, S.M., REAP, E.A., CARICCHIO, R., COHEN, P.L., EARP, H.S. and MATSUSHIMA, G.K. (2001). Phagocytosis and clearance of apoptotic cells is mediated by MER. Nature 411: 207-211.

SHIOZAWA, Y., PEDERSEN, E.A., PATEL, L.R., ZIEGLER, A.M., HAVENS, A.M., JUNG, Y., WANG, J., ZALUCHA, S., LOBERG, R.D., PIENTA, K.J. et al., (2010) GAS6/AXL Axis Regulates Prostate Cancer Invasion, Proliferation, and Survival in the Bone Marrow Niche. Neoplasia (New York, NY) 12: 116-127.

SHORS, T.J., MIESEGAES, G., BEYLIN, A., ZHAO, M., RYDEL, T. and GOULD, E. (2001). Neurogenesis in the adult is involved in the formation of trace memories. Nature 410: 372-376.

SIERRA, A., BECCARI, S., DIAZ-APARICIO, I., ENCINAS, J.M., COMEAU, S and TREMBLAY, M.E. (2014). Surveillance, phagocytosis, and inflammation: how never-resting microglia influence adult hippocampal neurogenesis. Neural plasticity 2014: 610343.

SIERRA, A., ENCINAS, J.M., DEUDERO, J.J., CHANCEY, J.H., ENIKOLOPOV, G. OVERSTREET-WADICHE, L.S., TSIRKA, S.E. and MALETIC-SAVATIC, M. (2010). Microglia shape adult hippocampal neurogenesis through apoptosis-coupled phagocytosis. Cell Stem Cell 7: 483-495.

STITT, T.N., CONN, G., GORE, M., LAI, C., BRUNO, J., RADZIEJEWSKI, C., MATTSSON, K., FISHER, J., GIES, D.R., JONES, P.F. et al., (1995). The anticoagulation factor protein $S$ and its relative, Gas6, are ligands for the Tyro 3/Axl family of receptor tyrosine kinases. Cell 80: 661-670.

TANG, H., CHEN, S., WANG, H., WU, H., LU, Q. and HAN, D. (2009). TAM receptors and the regulation of erythropoiesis in mice. Haematologica 94: 326-334.

TIE, J.K. and STAFFORD, D.W. (2008). Structure and Function of Vitamin K Epoxide Reductase. In Vitamins \& Hormones, vol. Volume 78. Academic Press, pp.103-130.

WANG, J., ZHANG, H., YOUNG, A.G., QIU, R., ARGALIAN, S., LI, X., WU, X. LEMKE, G. and LU, Q. (2011). Transcriptome analysis of neural progenitor cells by a genetic dual reporter strategy. Stem Cells 29: 1589-1600.

WANG, Y., ZHEN, Y., SHI, Y., CHEN, J., ZHANG, C., WANG, X., YANG, X., ZHENG, Y., LIU, Y. and HUI, R. (2005). Vitamin K Epoxide Reductase: A Protein Involved in Angiogenesis. Am. Assoc. Cancer Res. 3: 317-323.

WIERMAN, M.E., KISELJAK-VASSILIADES, K. and TOBET, S. (2011). Gonadotropinreleasing hormone $(\mathrm{GnRH})$ neuron migration: Initiation, maintenance and cessation as critical steps to ensure normal reproductive function. Front. Neuroendocrinol. 32: 43-52.

XIONG, W., CHEN, Y., WANG, H., WANG, H., WU, H., LU, Q. and HAN, D. (2008). Gas6 and the Tyro 3 receptor tyrosine kinase subfamily regulate the phagocytic function of Sertoli cells. Reproduction 135: 77-87.

YANAGITA, M., ISHIMOTO, Y., ARAI, H., NAGAI, K., ITO, T., NAKANO, T., SALANT, D.J., FUKATSU, A., DOI, T. and KITA, T. (2002). Essential role of Gas6 for glomerular injury in nephrotoxic nephritis. J. Clin. Invest. 110: 239-246.

ZAGORSKA, A., TRAVES, P.G., LEW, E.D., DRANSFIELD, I. and LEMKE, G. (2014). Diversification of TAM receptor tyrosine kinase function. Nat Immuno/ 15: 920-928.

ZELENTSOVA, K., TALMI, Z., ABBOUD-JARROUS, G., SAPIR, T., CAPUCHA, T., NASSAR, M., and BURSTYN-COHEN, T. (2016). Protein S regulates neural stem cell quiescence and neurogenesis. Stem Cells 35: 679-693.

ZELENSTOVA-LEVITSKYI, K., TALMI, Z., ABOUD-JARROUS, G., CAPUCHA, T. SAPIR, T., and BURSTYN-COHEN, T. (2017). Protein S negatively regulates neural stem cell self-renewal through Bmi-1 signaling. Front. Mol NeuroSci. 10.3389/fnmol.2017.00124.

ZHAO, C., DENG, W. and GAGE, F.H. (2008). Mechanisms and functional implications of adult neurogenesis. Cell 132: 645-660.

ZHU, D., WANG, Y., SINGH, I., BELL, R.D., DEANE, R., ZHONG, Z., SAGARE, A., WINKLER, E.A. and ZLOKOVIC, B.V. (2010). Protein S controls hypoxic/ischemic blood-brain barrier disruption through the TAM receptor Tyro3 and sphingosine 1-phosphate receptor. Blood 115: 4963-4972. 


\section{Further Related Reading, published previously in the Int. J. Dev. Biol.}

Expression of the DTK receptor tyrosine kinase during zebrafish development M Jansa Perez, J A Walshe, K E Crosier and P S Crosier

Int. J. Dev. Biol. (1996) 40: S101-S102

http://www.intjdevbiol.com/web/paper/9087716

Sexual dimorphism in estrogen-induced synaptogenesis in the adult hippocampus Nicola Brandt, Ricardo Vierk and Gabriele M. Rune

Int. J. Dev. Biol. (2013) 57: 351-356

http://dx.doi.org/10.1387/ijdb.120217gr

The spermatogonial stem cell niche in testicular germ cell tumors

Unai Silván, Alejandro Díez-Torre, Pablo Moreno, Jon Arluzea, Ricardo Andrade, Margarita Silió and Juan Aréchaga

Int. J. Dev. Biol. (2013) 57: 185-195

http://dx.doi.org/10.1387/ijdb.130068ja

Identification of side population cells in mouse primordial germ cells and prenatal testis Maria-Lucia Scaldaferri, Stefania Fera, Laura Grisanti, Massimo Sanchez, Mario Stefanini, Massimo De Felici and Elena Vicini

Int. J. Dev. Biol. (2011) 55: 209-214

http://dx.doi.org/10.1387/ijdb.092977ms

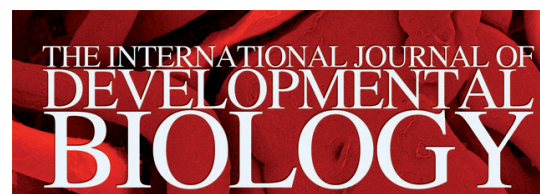

Volume 57 Nos. $2 / 3 / 4$

Special Issue
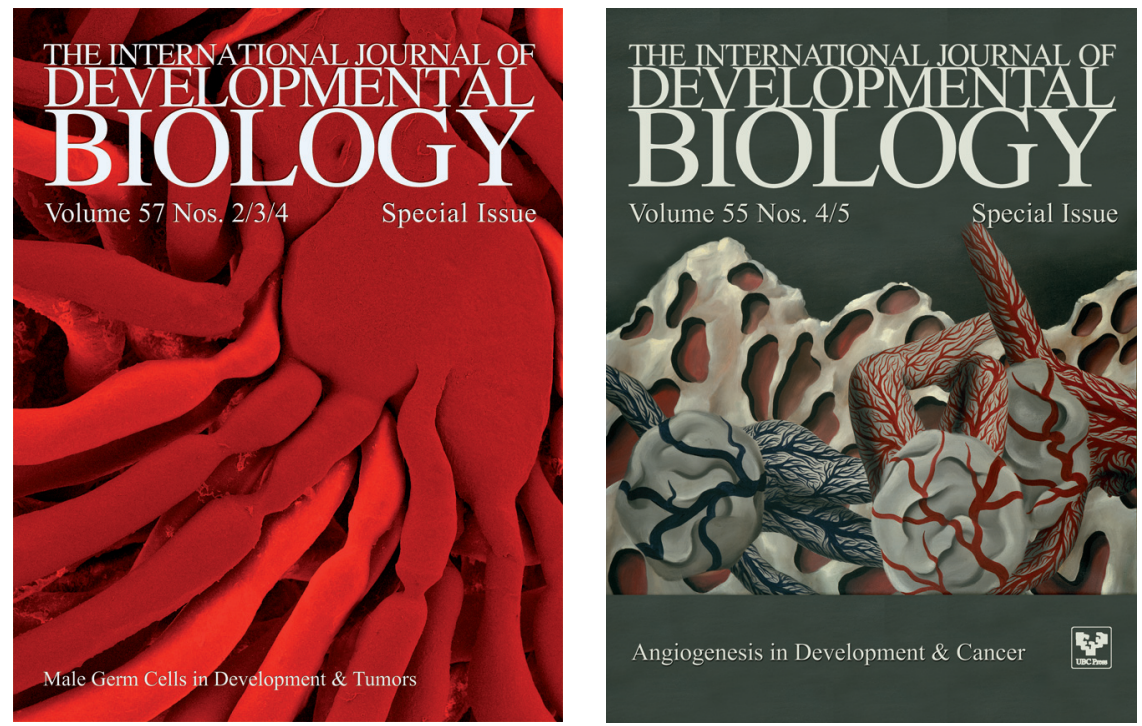
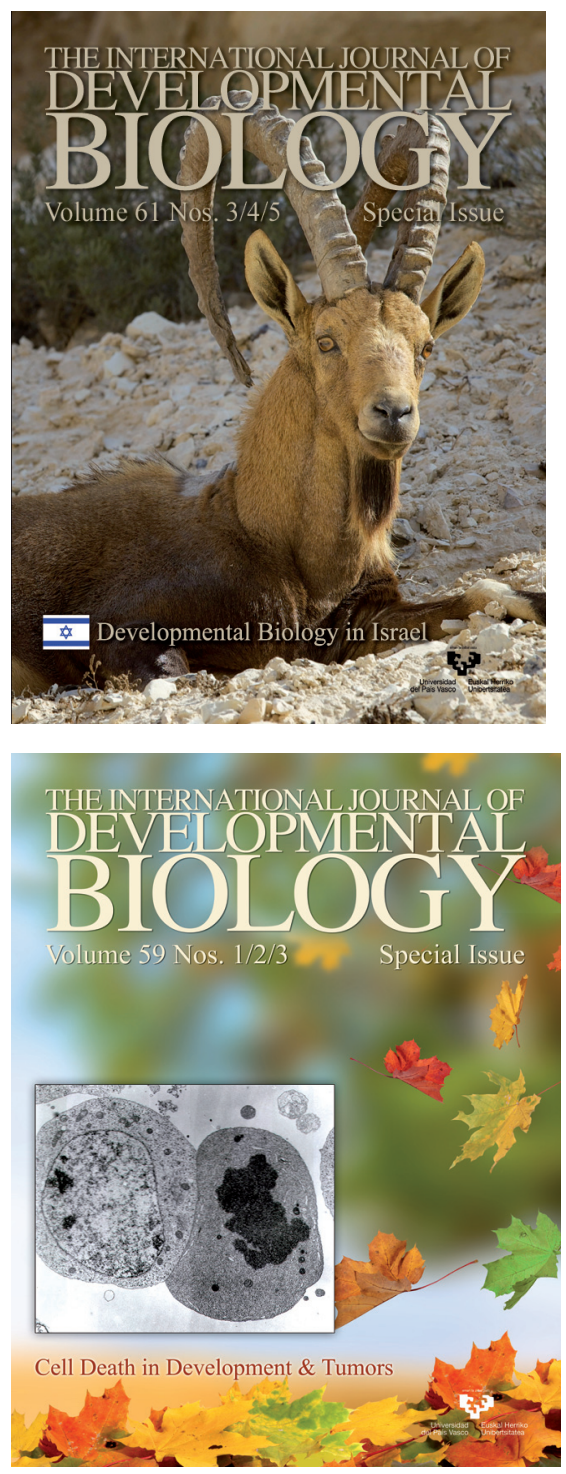